\title{
Diversidad, alteridad e identidad en la obra de Manuel Zapata Olivella: acerca de la teoría del mestizaje en La rebelión de los genes
}

Diversity, otherness and identity in Manuel Zapata Olivella:

About the theory of miscegenation in

La rebelión de los genes

Diversidade, alteridade e identidade na obra de Manuel Zapata Olivella: sobre a teoria da mestiçagem em

"La rebelión de los genes"

Fecha de entrega: 15 de diciembre de 2013

Fecha de evaluación: 15 de abril de 2014

Fecha de aprobación: 13 de junio de 2014

Edwin Cruz Rodríguez

\section{Resumen}

En su obra La rebelión de los genes, Manuel Zapata Olivella plantea una teoría del mestizaje en la que se concilia este concepto con la diversidad y la alteridad. El mestizaje no implica exclusión de la otredad ni eliminación de la diversidad. La diversidad no es subsumida en una

\footnotetext{
Doctorando en Estudios Políticos de la Universidad Nacional de Colombia, magister y especialista en Politica y Economía, profesional en Ciencia Política de la misma universidad. Ha efectuado investigaciones sobre lo público, las trasparencia y la violencia paramilitar en Colombia y ha publicado artículos sobre movimientos sociales e indigenas. Integrante del grupo de investigación en Teoría Política Contemporánea de la Universidad Nacional de Colombia. Correo electrónico: ecruzr@unal.edu.co
} 
sola identidad y la otredad no es una perspectiva ajena al sí mismo, sino constitutiva de su idiosincrasia. El otro es parte del sí mismo y el reconocimiento de tal situación constituye un proceso desalienador y descolonizador. Para explorar este planteamiento, en primer lugar, examinamos las concepciones de colonialismo y alienación, teniendo como eje articulador la categoría de idiosincrasia. Seguidamente, examinamos la relación entre diversidad y mestizaje en la teoría de Zapata Olivella. Luego, analizamos la relación entre su concepto de mestizaje y la alteridad. Finalmente, estudiamos el horizonte normativo de la descolonización y la desalienación.

Palabras clave: diversidad, alteridad, identidad, mestizaje, Zapata Olivella

\section{Abstract}

In his book La rebellion de los genes, Manuel Zapata Olivella raises a theory of the miscegenation that reconciles this concept with the diversity and the otherness. The miscegenation does not imply exclusion of otherness or elimination of diversity. Diversity is not subsumed under a single identity and otherness is not a perspective foreign to itself, but constitutive of his idiosyncrasy. The Other is part of the self and the recognition of this situation is a process of decolonization. To explore this approach, first examine the concepts of colonialism and alienation, with its central theme the category of idiosyncrasy. Next, we examined the relationship between diversity and miscegenation in the theory of Zapata Olivella. Then, we analyzed the relationship between the concept of miscegenation and the Other. Finally, we study the normative horizon of decolonization.

Keywords: Diversity, Otherness, Identity, Miscegenation, Zapata Olivella 


\section{Resumo}

Em seu livro "La rebelión de los genes", Manuel Zapata Olivella planteia uma teoria da mestiçagem na qual este conceito é reconciliado com a diversidade e a alteridade. A miscigenação não implica exclusão da otredade nem supressão da diversidade. A diversidade não é subsumida sob uma única identidade e a otredade não é uma perspectiva alheia para si mesmo, mas constitutiva de sua idiossincrasia. O outro faz parte do si mesmo e o reconhecimento desta situação constitui um processo desalienador e descolonizador. Para explorar essa abordagem, em primeiro lugar, examinamos as concepções de colonialismo e alienação, tendo como eixo articulador a categoria de idiossincrasia. Em seguida, vamos examinar a relação entre diversidade e miscigenação na teoria de Zapata Olivella. Logo após, analisar-mos-á a relação entre o seu conceito de mestiçagem e a alteridade. Finalmente, estudamos o horizonte normativo da descolonização e a desalienação.

Palavras-chave: diversidade, alteridade, identidade, mestiçagem, Zapata Olivella. 


\section{Introducción}

El mestizaje se erigió, desde la fundación de varias de las repúblicas latinoamericanas, como el fundamento de la identidad nacional. Se trata, como es sabido, de un fenómeno diverso. En algunos casos, como en Colombia, el mestizaje se esboza inicialmente como una etapa transitoria hacia la construcción de una sociedad "blanca" y, por tanto, "civilizada". Pero en otros, como México, Bolivia o Ecuador, se enuncia como el punto de llegada de la identidad nacional (Larson, 2004). Así planteado, el mestizaje se concibe como una síntesis racial y cultural entre de la comunidad nacional y, en consecuencia, como un factor de inclusión. Sin embargo, a fines del siglo XX, el mestizaje fue impugnado por movimientos indígenas y afro, que vieron en este un factor de exclusión de sus culturas, antes que de inclusión. En su perspectiva, el mestizaje se erigía o bien como un proyecto nacional asimilacionista, en el cual tenían que abandonar su identidad como indígenas o afro y transformarse en mestizos como condición para ser incluidos en la nación, o bien como la ideología de las élites dominantes, más que como factor de cohesión nacional.

En este contexto cabe preguntarse: ¿puede el mestizaje coexistir con el reconocimiento y la convivencia entre distintas culturas o es una categoría negadora y excluyente de la diversidad y la alteridad? La teoría del mestizaje de Manuel Zapata Olivella, enriquecida por la multiplicidad de su obra narrativa, antropológica y ensayística, apunta a una caracterización distinta de este fenómeno.

En La rebelión de los genes (Zapata, 1997), texto en el que encontramos más elaborado su planteamiento desde el punto de vista teórico, el mestizaje no excluye ni anula la diversidad y la alteridad. Se concibe como la idiosincrasia triétnica de los habitantes de América, producto de la mezcla biológica, étnica y cultural entre africanos, amerindios y europeos, no como una síntesis superior entre distintas etnias o culturas. Sin embargo, tal idiosincrasia ha sido velada por la alienación producto del colonialismo. En consecuencia, la descolonización pasa por un proceso de desalienación o toma de consciencia sobre la idiosincrasia triétnica, que a su vez implica el reconocimiento de la diversidad del ser y el reconocimiento de que el otro habita en el sí mismo.

Para explorar este planteamiento, en primer lugar, examinamos las concepciones de colonialismo y alienación, teniendo como eje articulador la categoría de idiosincrasia. Seguidamente, examinamos la relación entre diversidad y mestizaje en la teoría de Zapata Olivella. Luego, analizamos la relación entre su concepto de mestizaje y la 
alteridad. Finalmente, estudiamos el horizonte normativo de la descolonización y la desalienación.

\section{Colonialismo y alienación}

Zapata Olivella piensa en el concepto de la identidad a partir del lugar de enunciación afromestizo, en Colombia, a fines del siglo XX. El problema nodal que articula su intervención es el del colonialismo, que en su lectura implica sobre todo un proceso de alienación. Para conceptualizarlo, el autor parte de una diferencia, entre idiosincrasia e identidad. La identidad, en su perspectiva, es una categoría que designa una abstracción del ser y que, por lo tanto, varía. La idiosincrasia, por el contrario, es una categoría ontológica, determinante de la naturaleza del ser. En fin, la alienación es la imposición de una identidad ajena a la idiosincrasia de un sujeto. Como él mismo explica:

La idiosincrasia es inalienable (etimológicamente significa "temperamento propio" - por tanto inalienable-), hereda y determina la naturaleza del ser. La identidad es un concepto abstracto del ser, que puede cuestionarse, hipotecarse, venderse y negociarse [...] En cambio, la idiosincrasia jamás podrá enajenarse: 'genio y figura hasta la sepultura'. La génesis de toda alienación es el hecho por el cual una fuerza extraña al sujeto lo compulsa a asumir una conducta ajena a su propia idiosincrasia para comportarse con una identidad que lo niega. Los individuos y pueblos sometidos a largos procesos de aculturación, a manera defensiva, suelen introyectar en su subconsciente la angustia existencial, asumiendo como actos autónomos los mandatos del opresor. Tales fenómenos se acumulan en el reservorio de la memoria ancestral y se manifiestan en aptitudes y actitudes que disfrazan la autenticidad. Constituyen el esqueleto o el fantasma de los prejuicios y las alienaciones. (Zapata, 1997, p. 13)

Para Zapata, existe una idiosincrasia que ha sido velada como consecuencia de los procesos de aculturación que ha conllevado la colonización. A esta idiosincrasia la denomina "trietnicidad mestiza", para hacer referencia al proceso de mestizaje biológico y cultural que ha tenido lugar en América:

El trueque de valores entre amerindios, europeos y africanos fue tan intenso y permanente, que hoy es imposible conocer la dirección de los préstamos. 
Indudablemente sus frutos hubieran sido mucho más enriquecedores de reconocerse la riqueza espiritual de las culturas avasalladas. Pero se subestimaron sus lenguas, cultos religiosos, filosofía, moral y artes, considerándolas herejías y barbarie. Por fortuna, adversa a los prejuicios, la empatía de los sexos forjó el mestizaje triétnico que respondería a las necesidades de la vida y la naturaleza. (Zapata, 1997, p. 239)

De ahí el título de su obra, La rebelión de los genes, especie de revancha biológica que fuerza la necesidad del reconocimiento de esta idiosincrasia. La trietnicidad mestiza, la idiosincrasia, es un atributo ontológico que trasciende la identidad amerindia, africana o europea. Pero está velada por la alienación que ha traído el colonialismo, la servidumbre y la esclavización y nos impide ser auténticos. Aunque la trietnicidad latinoamericana es evidente, existen enmascaramientos para no asumirla, como la hipótesis del exterminio total de los aborígenes. Además, la alienación o enajenación no solo está conectada con la falta de originalidad, sino también con las desigualdades persistentes y el "atraso" al que nos condena el fatalismo de nuestra mentalidad alienada por el hecho de no ser como los europeos:

En el ocultamiento de los orígenes se asientan todas las formas de 'machismo' —sexual, cultural, social_-, pues se menosprecia el preponderante designio de las mujeres indígena y africana como receptoras de la vida y transmisoras de la cultura. Al ocultar o desconocer nuestra herencia, se destruyen los basamentos históricos de la originalidad de la cultura americana — su mestizaje —, reduciéndola a una sombra desteñida al reflejo de Europa y de otros continentes. También se perpetúan las diferencias étnicas y culturales, aunque no se expresen en actitudes y conceptos. Vergonzante discriminación que niega la propia idiosincrasia para eludir la responsabilidad de la autodefensa. (Zapata, 1997, p. 242)

Para Zapata, el colonialismo con sus consecuencias de alienación no terminó con la Independencia. La Independencia no implicó la ruptura del dominio de la casta "blanca". Aunque se reivindicaran los principios románticos de libertad, igualdad y fraternidad y los derechos del hombre, se mantuvieron la servidumbre indígena y la esclavitud africana. "Doscientos años después de nuestra independencia, todavía debemos hablar de descolonización económica y cultural” (Zapata, 1997, p. 340). Además, en la perspectiva de Zapata aún no ha habido "descubrimiento", pues eso 
implicaría reconocernos como lo que somos, ser conscientes de nuestra idiosincrasia triétnica y, por lo tanto, desalienarnos. "La independencia política y económica no trajo cambios radicales. La noche de la colonización persiste en oponerse al sincretismo de las sangres. 'Libertad', 'igualdad', 'fraternidad', son conceptos que no han traspasado el umbral de la utopía” (Zapata, 1997, p. 281).

En fin, el colonialismo tiene como consecuencia un proceso de alienación por el cual la idiosincrasia, la naturaleza del ser, es velada por la imposición de una identidad ajena. Esa idiosincrasia oculta es la trietnicidad mestiza, producto del mestizaje biológico, étnico y cultural que tiene lugar en América, entre amerindios, europeos y africanos. La alienación está articulada a las situaciones de desigualdad y opresión persistentes, pues el colonialismo no terminó con la Independencia. Así, aún no ha habido descubrimiento que implicara una desalienación o toma de consciencia sobre nuestra idiosincrasia triétnica y el carácter diverso de los seres humanos que habitan América.

\section{Diversidad y mestizaje}

En la teoría del mestizaje de Zapata Olivella, la diversidad no se presenta como un problema que debe ser reducido. Por el contrario, la diversidad es constitutiva de la idiosincrasia, que se trata de reivindicar como condición para la desalienación. A diferencia de la interpretación dominante del concepto de mestizaje, entendido como mezcla de razas y orientado a la unidad, en Zapata Olivella el mestizaje es sinónimo de diversidad. Así, se distingue de concepciones como la de José Vasconcelos.

En efecto, Vasconcelos admite la existencia de cuatro razas: “[...] el negro, el indio, el mongol y el blanco" (1999, pp. 10-11). Para él, en la América española existen las condiciones para que estas razas se fundan y constituyan "[...] una quinta raza universal, fruto de las anteriores y superación de todo el pasado”. De esa manera, el mestizaje en la obra de Vasconcelos supone una negación de la diversidad. Esta debe desaparecer para, en una síntesis análoga a la hegeliana, formar una sola raza, superior y universal:

En la América española ya no repetirá la Naturaleza uno de sus ensayos parciales, ya no será la raza de un solo color, de rasgos particulares, la que en esta vez salga de la olvidada Atlántida; no será la futura ni una quinta ni una sexta 
raza, destinada a prevalecer sobre sus antecesoras; lo que de allí va a salir es la raza definitiva, la raza síntesis o raza integral, hecha con el genio y con la sangre de todos los pueblos y, por lo mismo, más capaz de verdadera fraternidad y de visión realmente universal. (Vasconcelos, 1999, p. 36)

Como veremos, el concepto de mestizaje de Zapata Olivella se diferencia del de Vasconcelos en, por lo menos, tres sentidos: en primer lugar, no refiere a una síntesis racial, que anule su diversidad constitutiva, sino de la toma de consciencia sobre tal diversidad, sobre la idiosincrasia triétnica. Por lo tanto, y en segundo lugar, no es solo un mestizaje futuro, un proyecto, sino también el reconocimiento de una forma de ser, un proceso que liga pasado, presente y futuro. Finalmente, aunque en ambos casos hay una apuesta por el universalismo basada en el mestizaje, en la concepción de Zapata Olivella no se trata de un universalismo abstracto producto de la subsunción de distintas razas o culturas en el crisol del mestizaje, sino de una forma de universalismo concreto, que comprende los particulares, en lugar de erigir uno de ellos - el ser mestizo como una forma de ser distinta al ser afro, amerindio o blanco- como una particularidad hegemónica que representa las demás.

El concepto de mestizaje de Zapata Olivella es una articulación compleja entre lo étnico o biológico y lo cultural (1997, p. 115), de la "[...] compleja simbiosis entre genética y cultura” (1997, p. 338). Para él, se trata de una realidad histórica y empíricamente constatable y de un hecho positivo y natural de enriquecimiento cultural y genético, que se recrea permanentemente sin llegar a ser una síntesis última, no de un concepto excluyente o aniquilador de la diversidad:

La evolución de los animales y vegetales, así como la del propio hombre, nos revelan que la hibridación es la ley natural que genera la aparición de nuevas especies. Desde luego, el mestizaje biológico no presupone ni busca el exterminio de las etnias. Todo lo contrario, necesita su perpetuidad como fuente de nuevas hibridaciones. (Zapata, 1997, p. 367)

La idiosincrasia latinoamericana es lo que Zapata denomina trietnicidad, producto del mestizaje entre indígenas, africanos y europeos, y no solo es una constatación, sino también un proyecto, dado que es necesario reconocerla, tomar consciencia de esta como condición para la desalienación. Pero, en primer lugar, es una realidad negada o no reconocida. 
El mestizaje es una constatación empírica e histórica, porque, en su perspectiva, es imposible que las poblaciones se hubiesen mantenido al margen de su dinámica étnica y cultural. Los africanos llegados a América procedían de un tronco común, cuyos ancestros habían circunvalado el mundo, sus descendientes se volvían a encontrar en el continente, pero en África había ya un mestizaje étnico y cultural (Zapata, 1997, p. 119). Asimismo, al llegar los españoles a América ya existía una dinámica de mestizaje entre los aborígenes americanos (Zapata, 1997, pp. 168-169), y entre los españoles mismos se habían presentado cruces étnicos e hibridaciones culturales con los moros y otros pueblos europeos y africanos. El intercambio de valores hace muy difícil o imposible establecer cuáles personas son realmente indígenas, blancos o africanos (Zapata, 1997, p. 273). Tales valores pueden percibirse en la cultura, en la lengua, en la religiosidad y en la música.

El mestizaje también se soportó en las tácticas lingüísticas que emplearon las comunidades oprimidas para preservar los valores de su cultura. Los pueblos e individuos africanos en condiciones de opresión dieron nuevas connotaciones a las palabras del idioma del opresor y lo enriquecieron (Zapata, 1997, p. 280). En el proceso de aculturación, recibieron y asimilaron valores lingüísticos de los opresores y recrearon sus valores en el mestizaje con otras etnias. Esto se puede apreciar cuando se estudia la tradición oral: allí existieron intercambios lingüísticos entre indígenas, africanos y europeos, comunidades analfabetas y semiletradas con profuso mestizaje, hasta el punto de no poder determinar los orígenes (Zapata, 1997, pp. 280-281).

Finalmente, el Santo Oficio impidió que los cultos a los muertos amerindios y africanos se practicaran libremente. Pero estos ritos persistieron a través de la adoración a los santos católicos, de ahí que ocurrieran diversas formas de sincretismo religioso (santería, vodú, candomblé, fiestas patronales, música y cantos populares) (Zapata, 1997, pp. 287-288). Esto, en buena medida, se debió a los intercambios, principalmente orales, entre colonizadores y colonizados, pero también a la favorabilidad de las religiones africanas, como el muntú, para articularse al catolicismo, en cuanto compartían principios ecuménicos (Zapata, 1997, pp. 294-295). Así, no solo hubo una superposición de estructuras religiosas, sino también un enriquecimiento mutuo. Del mismo modo, el mestizaje se puede constatar en la música popular, instrumentos, bailes, etc. que se dieron como resultado de una empatía de culturas (Zapata, 1997, pp. 297-298). 
En suma, la teoría del mestizaje de Zapata Olivella no anula la diversidad para subsumirla en una sola identidad, el ser mestizo. Presupone el reconocimiento de un proceso histórico de enriquecimiento biológico, étnico y cultural entre las distintas culturas que habitan América. Pero también implica un proyecto, desalienador y descolonizador, que pasa por la toma de consciencia de la idiosincrasia triétnica y, por lo tanto, de la otredad que habita en el yo o en el sí mismo.

\section{Alteridad o el otro que habita en mí}

En la teoría del mestizaje de Zapata Olivella, la otredad no existe como una perspectiva externa al sí mismo. Por el contrario, la otredad es constitutiva de la idiosincrasia y solo existe como otredad desde el punto de vista de la alienación. Por eso, su concepto de mestizaje no es excluyente de la otredad. No se es mestizo como algo o alguien distinto, como una síntesis superior o algo por el estilo del afroamericano, el europeo o el amerindio. Se es mestizo justamente porque se es simultáneamente los tres pudiendo ser también uno de ellos. En consecuencia, no estamos frente a un esencialismo de la identidad. La toma de consciencia sobre la idiosincrasia triétnica y el ser mestizo, que se recrea permanentemente, implica una renuncia a la aspiración de tener una identidad definitiva de una vez y para siempre. Los seres humanos son por definición diversos.

No puede confundirse este concepto de mestizaje con el de una simple mezcla racial, cuyo resultado es un fenotipo o una cultura distinta o de síntesis entre las que la preceden. En el pensamiento de Zapata, al ser afroamericano, amerindio o "blanco", se es simultáneamente mestizo. No hay purezas étnicas desde esta perspectiva. El mestizaje no desconoce la particularidad, no anula ni subsume el punto de vista del otro, sino reúne los distintos puntos de vista y enriquece la mirada. No tiene nada que ver con el color de la piel. Por ejemplo, refiriéndose a nuestra ascendencia africana afirma Zapata:

Es necesario resaltar que esa descendencia mestiza no forzadamente ha conservado la tez negra, puesto que las hibridaciones étnicas han generado diversidad de fenotipos que, desde entonces hasta hoy, vienen multiplicándose y dando nuevos y más variados tipos humanos. En tal sentido, cuando hablamos de una diáspora africana, deseamos concretar que aludimos a aquellos valores étnicos y culturales que han preservado los genotipos y pensamientos 
directamente ligados a las culturas negras de África [...] Estamos hablando de más de trescientos millones de mestizos y mulatos de América y de otros millones de Europa y Asia. (Zapata, 1997, p. 364)

En el mismo sentido, refiriéndose a nuestra ascendencia amerindia dice:

La americanidad exige la total identificación del mestizaje americano con la cultura autóctona que le ha nutrido y lo especifica. El aborigen no solo existe por fuera de nosotros, sino que es parte consubstancial de nuestra biología, nuestro pensamiento, nuestras costumbres y nuestras actitudes. No es necesario que descubramos tal abuelo o abuela en la ascendencia; que tengamos oblicuos los ojos o flechudos los cabellos. Basta con saber que la colonización de América se construyó sobre los cimientos ecológicos del aborigen; del aprovechamiento de sus alimentos, viviendas, artesanías, costumbres, herramientas de trabajo y, sobre todo, del mestizaje propiciado por el conquistador con la mujer indígena y africana, para que aceptemos su presencia en cada una de las aristas triétnicas de nuestra identidad. (Zapata, 1997, p. 147)

Finalmente, concluye el autor:

Ahora bien, volviendo a nuestra singularidad cultural, esta es el mestizaje triétnico. Al referirnos a esta hibridación de razas y culturas no estamos aludiendo a que cada individuo sea forzosamente un mestizo, mulato o zambo en su biología individual. Puede ser un afro puro; un criollo o un indígena sin mezclas. Pero no por ello, si su condición de colombiano a americano es el resultado de un proceso histórico - porque no es un recién llegado de otro continente-, puede substraerse al acervo multirracial y multicultural de su origen. En alguna forma o en otra dará prueba de estar alimentado por ese espíritu triétnico subyacente en las culturas nacionales americanas y que se expresa en la lengua, los sentimientos y la filosofía de nuestros pueblos. (Zapata, 1997, p. 143)

Por todo esto, el concepto de mestizaje de Zapata no implica una subordinación entre distintas culturas o etnias. Esta crítica es planteada por González de Allen (2006, p. 9) quien argumenta que la recuperación de la idiosincrasia triétnica no cumple 
con el objeto de desestabilizar la ideología racista, puesto que el mestizaje ha sido principalmente una afirmación de la "blancura" y no de la solidaridad multiétnica y multicultural. Por tanto, un proyecto de lucha contra la opresión racial no puede fundarse en la mezcla de razas, pues esta continúa invisibilizando y subordinando la negritud. Este tipo de críticas asimilan el concepto de mestizaje de Zapata Olivella a los conceptos dominantes de mestizaje. Sin embargo, como se ha visto, el concepto de mestizaje de Zapata no implica entender que este se deba dirigir hacia la formación de una raza, etnia o cultura que sintetice, subsuma o supere las que le dan origen y, en consecuencia, no implica un proyecto de "blanqueamiento".

Lo que plantea Zapata es que el racismo y todas las formas de dominación producto del colonialismo afectan tanto al colonizador como al colonizado. De esta manera, la lucha contra estos pasa por pensar arreglos que permitan la convivencia entre las culturas, la convivencia con el otro. La lucha contra la ideología racista no implica, desde esta perspectiva, hacer del oprimido un verdugo de su opresor, sino buscar alternativas de convivencia con él, puesto que el racismo es una manifestación de alienación de ambos. Por consiguiente, para que esta forma de convivencia se produzca, es necesaria la desalienación tanto del opresor o colonizador como del oprimido o colonizado.

Precisamente, según Zapata Olivella, el otro solo existe como una proyección de mi pusilanimidad y de mi condición de alienado, de mi incapacidad para reconocerme, para reconocer mi idiosincrasia:

No hay nada más aberrante que aquellos mestizos que imaginan, amputándose su propia idiosincrasia, que la lucha del aborigen marginado no les incumbe. Y lo abandonan con sus plumas, sus flechas y su selva. Nada más distante de su propia etnia, de los límites de su dependencia, su libertad y su condición humana, que la asumida por los 'blancos' mestizos cuando se consideran descendientes impolutos de unos europeos que no lo eran al pisar estas tierras y que posteriormente fundieron su vida al destino de un pueblo que nacía con tres sangres y una cabeza multipensante. (Zapata, 1997, p. 46)

De igual forma, “[...] observar con mirada resentida al mestizo de hoy, solo conduce a compulsar del lado del discriminador a la mayoría de los discriminados" (Zapata, 1997, p. 313). En realidad, el otro es interno al sí mismo o al mí mismo, solo existe 
como parte de mí mismo, de mí origen, sin que ello implique un desconocimiento o una anulación de su particularidad. Si no se reconoce esto y se sigue mirando al indio como indio, como alguien ajeno a uno mismo, es porque se está alienado y, por tanto, no se reconoce el carácter triétnico de la propia idiosincrasia. Por eso, se trata de "[...] descubrir la pusilanimidad de quienes se resisten a mirarse en el espejo de su propia historia” (Zapata, 1997, p. 243). En este sentido, en Zapata el conocimiento de sí mismo, de la idiosincrasia, pasa por el conocimiento y reconocimiento del otro. En otros términos, el proceso de desalienación pasa necesariamente por el reconocimiento de que "yo soy el otro". Solo de esa forma se puede tomar consciencia del carácter diverso e irreductible del ser mestizo.

Estas concepciones cuestionan tanto el mestizaje genérico que pretende crear una unidad que excluye las otredades como aquellas perspectivas puristas que se niegan a aceptar la diversidad del ser y erigen el punto de vista de una identidad, llámese blancos civilizados, afrodescendientes puros o indígenas puros, como la perspectiva a partir de la cual concebir la identidad o, en la terminología de Zapata, la idiosincrasia.

Zapata cuestiona la concepción de superioridad cultural que se mantiene en este tipo de perspectivas. Parte de la constatación de que el colonialismo es sobre todo una apropiación de las fuerzas creadoras, materiales y espirituales de los pueblos. En la colonización americana no solo se requirieron los aborígenes americanos, sino también la creatividad de otros pueblos, los africanos (Zapata, 1997, pp. 237-238). Pero el conocimiento no puede transmitirse sin ser recreado, toda criatura humana tiene un don creador (Zapata, 1997, p. 238). Así, en la colonización no solo hubo imposiciones, el colonizado y el esclavizado modificaron y enriquecieron la cultura del colonizador, y este no fue ya el mismo, aunque la creencia contraria se ha introyectado en la memoria y la consciencia de los colonizados: existe así la leyenda de barbarie y canibalismo, de exterminio total de culturas aborígenes o de empobrecimiento biológico del mestizo, ignorando la perpetuidad biológica (Zapata, 1997, p. 239). Desde esta perspectiva, América enriqueció la civilización europea tanto como esta nos enriqueció:

El Amazonas caudaloso inundó las aguas de Europa para enriquecerlas con sus orígenes. El océano de la civilización no podrá sustraerse de su caudal [...] El coletazo de Europa en nuestras culturas, a la par de quebrantar muchos huesos, vigorizó nuestras sangres. Lo lúcido es reconocer la riqueza de nuestra endoculturación por el flujo renovador de Europa y África. (Zapata, 1997, p. 240) 
Zapata devela la concepción de la barbarie, tornándola más bien una forma distinta de civilización, cultural, tecnológica y social no reconocida por el colonizador (Zapata, 1997, pp. 170, 248). A propósito de esto, dice “[t]odos los pueblos que practicaban religiones distintas a las de los esclavistas o que se resistían a la pérdida de la libertad, eran considerados 'bárbaros' aunque los superaran en pensamiento religioso y ético” (Zapata, 1997, p. 248).

Esto le permite afirmar que los europeos recibieron más de lo que aportaron a la colonización de América: alimentos, plantas medicinales, herramientas, viviendas y vestidos de los aborígenes, conocimientos del medio ecológico, indispensables para que el colonizador se adaptara a un medio ambiente desconocido; pero no se ha hecho justicia al aporte de aquellos protagonistas anónimos (Zapata, 1997, p. 239). Siempre hubo una respuesta a la imposición de la cultura del colonizador, una "creatividad bajo presión” (Zapata, 1997, p. 252; 1999, pp. 93-140). El conocimiento acumulado por los cronistas sirvió a los conquistadores para colonizar, pero también nutrió su cultura: palabras, plantas, costumbres, instrumentos, etc.

En resumen, la de Zapata es una perspectiva en la que la otredad no solo se reconoce sino se incluye como constitutiva de la identidad o idiosincrasia sin hacer que pierda su propia singularidad. El otro solo existe como algo externo al sí mismo en condiciones de alienación que impiden el reconocimiento de la idiosincrasia, de la trietnicidad americana. El otro, amerindio, afroamericano o europeo, es constitutivo de la idiosincrasia americana y de la diversidad de formas de ser producto de sus mezclas. Reconocer este hecho es parte de un proceso emancipatorio y descolonizador.

\section{Idiosincrasia, desalienación y universalismo concreto}

El problema, para Zapata, es que nuestra idiosincrasia, el mestizaje triétnico, no se reconoce a causa de la alienación que supone el colonialismo. Esta situación no solo afecta a los oprimidos, sino también a los opresores, pues también les impide tomar consciencia de esa idiosincrasia y no se ha superado en quinientos años. Así, el mestizaje no es un mestizaje racial futuro como el de Vasconcelos, es algo que existe ahora, pero que nuestra alienación nos impide reconocer. Por esta razón, el concepto de mestizaje también permite a formular un proyecto desalienador. Zapata enuncia este proyecto así: 
[...] no aspiramos a erigirnos en inquisidores modernos de teorías racistas. Al predicar la desalienación perseguimos exaltar una verdad biológica que tiene el valor de cualquier conocimiento astronómico: confirmar si somos estrella con luz propia o satélite reflector, sin que por ello se desarticule la gravitación universal ni la familia humana. Allí está lo incuestionable: el mestizo es más rico en variedad genética que sus progenitores, asúmase o no el compromiso de desarrollar su inteligencia y creatividad. (Zapata, 1997, p. 343)

La descolonización implica superar actitudes mentales y comportamientos heredados de la esclavitud. (Zapata, 1997, p. 282)

El primer paso a la real emancipación del amerindio, desnudo o aculturado, debe ser un acto de lucidez, la toma de consciencia de su propia identidad. (Zapata, 1997, p. 44)

Si la alienación es carencia de consciencia para reconocerse como triétnico, la desalienación pasa, entre otras cosas, por conformar un reconocimiento sobre nuestra idiosincrasia. Para esto, es necesario hacer varios desplazamientos en la forma como se ha entendido y hecho la historia. Primero, hay una reivindicación de lo anónimo que le sirve a Zapata para formular otra forma de ver la historia:

\footnotetext{
En la interpretación de los hechos socioeconómicos que dividieron la historia en dos (Antigüedad y Modernidad), debe partirse de esta premisa fundamental: los reales constructores del Nuevo Mundo fueron los arquitectos anónimos de América, África y Euroasia. En el plano teórico pueden darse todas las especulaciones posibles, pero sin la creatividad del hombre, llámese esclavo, siervo, obrero o amo, no hay cultura. Afirmar lo contrario es solo un sofisma para glorificar la intervención de la providencia y sus secuaces emperadores, guerreros o genios. (Zapata, 1997, p. 240)
}

Segundo, esto lo lleva a cuestionar las periodizaciones y los compartimientos estancos que han hecho comprensible la historia dominante. América no comenzó a existir desde el descubrimiento, existía antes y por eso su historicidad no puede dividirse en pre- y poshispánica (Zapata, 1997, p. 240). Tercero, como hemos visto, existe una valoración distinta de hechos como la Conquista y la Independencia. En la perspectiva de Zapata, aún no ha habido descubrimiento, pues eso implicaría reconocernos 
como somos y, por lo tanto, desalienarnos. A partir de esta afirmación, va a desplegar una estrategia investigativa centrada en el rescate de la tradición oral, del ágrafo y el analfabeto, metodológicamente indicada para rastrear los intercambios culturales que tuvieron lugar sobre todo por vía oral:

La palabra viva, ignorante de la escritura, aunque pierda memoria recrea el pensamiento, el lenguaje y la rebeldía. Por ocultos meandros del cerebro, el letrado y el ágrafo reciben y transmiten por igual a sus descendientes las experiencias indispensables para su vida e historia. Pero la voz-mariposa, inmovilizada por la letra, puede convertirse en espejo que nos informa como verdades las mentiras que sirvieron para esclavizarnos. Principalmente a lo que concierne nuestra verdadera historia. (Zapata, 1997, p. 282)

La tradición oral no es un simple receptáculo de experiencias y pensamientos de los pueblos, sino la palabra de apoyo para preservar su propia cultura, asimilar las extrañas y recrearlas en nuevos fenómenos étnicos, sociales, políticos y económicos (Zapata, 1997, p. 284).

Así, según Zapata Olivella, la historia no es un lastre, algo que hay que negar, sino algo que se debe asumir, que nos permitirá tomar consciencia de nuestra idiosincrasia. Aquí emancipación no significa enterrar la tradición, sino reconocerla. No se pretende partir de cero, asumir la propia identidad es una condición para desalienarse o emanciparse.

Una primera instancia sería destorcer su historia, tejida con su sangre pero dictada al capricho de sus opresores. Un segundo acto es el conocimiento de lo que se es -óigase bien, de lo que se es y no de lo que fue o quisiera ser-, para ubicarse correctamente como arteria nutricia del irreversible mestizaje. De esta manera, es posible comportarse con autenticidad, afirmando en el esclarecimiento y la lucidez de sí mismo (Zapata, 1997, p. 45).

Finalmente, este proyecto de emancipación universal se proyecta hacia el futuro con la filosofía bantú del muntú. Esta ayudó a los esclavizados de la diáspora africana a resistir la esclavización y los vivificará en el mestizaje futuro: “[u]na sola familia, estrechamente ligada a los muertos, los animales, los árboles y la naturaleza. Esto 
es lo que predican los pueblos bantúes de África con el concepto de 'muntú' [...]" (Zapata, 1997, p. 294).

Esto muestra claramente que el pensamiento de Zapata Olivella es universalista (Mina, 2006, p. 14). Sin embargo, se trata de una forma de universalismo particular, un "universalismo concreto" o un "pluriversalismo" . En esta perspectiva, el universalismo abstracto es la imposición de una forma particular de ser sobre la totalidad, desconectada de su contexto cultural y, más aún, de su ser concreto, de su lugar particular en el mundo. Así, anula o desconoce todos los particulares, los otros y la diversidad, bajo su propia hegemonía. En contraste, el universalismo concreto de Zapata no se basa en una norma o una definición abstracta del sujeto, como lo puede ser el individuo liberal, sino en su ser concreto con su carácter intrínsecamente diverso. La particularidad, en este universalismo concreto, es un crisol de otras particularidades, no una representación hegemónica de la totalidad. De allí que sea posible la igualdad en la diferencia.

El mestizaje interétnico y cultural adquiere importancia en el mundo actual caracterizado por las migraciones, "una moderna etapa de la diáspora africana” (Zapata, 1997, p. 341). Tal vez una forma de afirmarlo pueda encontrarse en la filosofía muntú de los bantúes, como código básico de comportamiento ecuménico con los principios elementales de sobrevivencia y convivencia entre hombres y naturaleza. "El muntú concibe la familia como la suma de los difuntos (ancestros) y de los vivos, unidos por la palabra a los animales, los árboles, los minerales (tierra, agua, fuego, estrellas) y las herramientas, en un nudo indisoluble" (Zapata, 1997, p. 362).

En síntesis, la desalienación o toma de consciencia sobre la idiosincrasia triétnica implica que el concepto de mestizaje de Zapata también es un proyecto. Un proceso que pasa por la recuperación de la historia velada por los relatos coloniales y rescata las tradiciones ágrafas de los subalternos, así como se proyecta al futuro con la filosofía bantú del muntú. Configura así un proyecto emancipatorio que reivindica un universalismo concreto.

\section{Conclusión}

En su obra La rebelión de los genes, Manuel Zapata Olivella plantea una teoría del mestizaje que concilia este concepto con la posibilidad de diversidad y la alteridad. 
El mestizaje no implica exclusión de la otredad ni eliminación de la diversidad. La diversidad no es subsumida en una sola identidad y la otredad no es una perspectiva ajena al sí mismo, sino constitutiva de su idiosincrasia. El otro es parte del sí mismo y el reconocimiento de tal situación constituye un proceso desalienador y descolonizador.

Desde la perspectiva de Zapata, el colonialismo implica un proceso de alienación que impone una identidad ajena sobre la idiosincrasia. En América esa idiosincrasia es la trietnicidad mestiza producto del mestizaje biológico y cultural entre indoamericanos, africanos y europeos. Es una característica ontológica que va más allá de la identidad amerindia, africana o europea. La descolonización y desalienación pasan por la toma de consciencia sobre esa idiosincrasia y es un proceso que no se ha conseguido.

En la teoría del mestizaje de Zapata, la diversidad no es un problema a ser reducido o negado, sino es constitutiva de la idiosincrasia. El mestizaje, a diferencia de sus acepciones dominantes, no implica solamente una mezcla de razas ni está orientado a una unidad o una síntesis superior. No solo es un mestizaje futuro, un proyecto, sino también la toma de consciencia sobre el carácter triétnico y mestizo de nuestro ser americano. El concepto de mestizaje de Zapata articula lo étnico o biológico y lo cultural; es una realidad histórica y constatable empíricamente que se recrea permanentemente sin agotarse en una síntesis última, pero también es un proyecto emancipatorio, descolonizador y desalienador. En ese sentido, el mestizaje no niega, excluye o aniquila la diversidad. En Zapata, el conocimiento de sí mismo, de la idiosincrasia, pasa por el conocimiento y reconocimiento del otro. En otros términos, el proceso de desalienación pasa necesariamente por el reconocimiento de que "yo soy otro". Así, cuestiona tanto el mestizaje genérico, que afirmando la síntesis racial, excluye o reduce la otredad y la diversidad, como las perspectivas puristas de la identidad, que también lo excluyen. Zapata cuestiona la concepción de superioridad cultural que se mantiene en este tipo de perspectivas, pues concibe el colonialismo como una apropiación de la creatividad de los pueblos colonizados y al mismo tiempo como un proceso que enriquece culturalmente tanto al colonizador como al colonizado.

De la misma forma, este concepto de mestizaje no excluye la otredad, sino la hace constitutiva de la idiosincrasia. La otredad solo existe como tal desde el punto de vista de la alienación, como la incapacidad de tomar consciencia de la idiosincrasia triétnica. El mestizaje no se entiende como una síntesis racial, no se es mestizo como alguien distinto al africano, amerindio o europeo. En consecuencia, no es una concepción esencialista de la identidad, dado que la idiosincrasia triétnica, el ser mestizo, se recrea 
en forma permanente. No se trata de un concepto que afirme un tipo de pureza étnica. El mestizaje no subsume o anula el punto de vista del otro, sino enriquece la mirada al reunir las distintas perspectivas, por tanto, reconoce su singularidad. Tampoco implica una subordinación de distintas culturas, en particular de la negritud, pues el mestizaje no se entiende como un proceso de blanqueamiento creciente, sino como la aceptación y la toma de consciencia del carácter diverso del ser. Por tanto, la lucha contra el racismo no se piensa como hacer del oprimido un verdugo de su opresor, sino encontrar formas de convivencia entre culturas que parten del reconocimiento del otro que habita en el sí mismo.

El problema fundamental, en la raíz de todos los “machismos" u opresiones, es que la idiosincrasia no se admite por la alienación propia del colonialismo. Por esta razón, la desalienación, como toma de consciencia de la idiosincrasia triétnica, plantea que el concepto de mestizaje también es un proyecto. Implica una recuperación de la historia velada por los relatos coloniales que rescata las tradiciones orales y ágrafas de los subalternos, pues la historia permite tomar consciencia de la idiosincrasia. Un proyecto de emancipación que se proyecta hacia el futuro y hacia la universalidad con la filosofía bantú del muntú. Configura, de esa manera, un pensamiento universalista, que reivindica un universalismo concreto, pues comprende todas las particularidades en vez de erigir una de estas como universal o como particularidad hegemónica representante de la totalidad. Los seres humanos son universales, en el sentido de ser diversos y, a la vez, capaces de comprender la alteridad.

Por todo esto, la construcción de Zapata puede ser interpretada como una alternativa de pensamiento frente al multiculturalismo, que como condición para la convivencia entre culturas plantea la necesidad de mantenerlas aisladas, pero también frente a los particularismos y purismos identitarios, incapaces de dialogar con la diversidad y la alteridad. En fin, su teoría del mestizaje apunta a un proyecto ecuménico de igualdad humana. 


\section{Referencias}

Cáceres Aguilar, D. (2007). Changó el gran putas: reconfiguración de la historia. Reinventando caminos para no olvidar. Poligramas, (28), 227-246.

Díaz-Granados, J. (2003). Manuel Zapata Olivella: La forja de un rebelde. En P. Torres y T. Grosch , Eds., Vida y obra: semblanzas (pp. 250-289). Bogotá: Ministerio de Cultura.

Garcés González, J. (2002). Manuel Zapata Olivella, caminante de la literatura y de la historia. Bogotá: Ministerio de Cultura.

Goméz-Muller, A. (1997). Alteridad y ética desde el descubrimiento de América. Madrid: Akal.

González de Allen, G. (2006). Enrique Dussel and Manuel Zapata Olivella: An exploration of Decolonial, Diasporic, and Trans-modern Selves and the Politics of Recongnition. Worlds \& Knowledges Otherwise, 1 (3), 1-12.

Grosfoguel, R. (2007). Descolonizando los universalismos occidentales: el pluriversalismo transmoderno decolonial desde Aimé Césaire hasta los zapatistas. En S. Castro Gómez y R. Grosfoguel, Eds., El giro decolonial. Reflexiones para una diversidad epistémica más allá del capitalismo global (pp. 63-77). Bogotá: Siglo del Hombre.

Larson, B. (2004). Trials of Nation Making: Liberalism, Race, and Ethnicity in the Andes 1810-1910. Cambridge: Cambridge University Press.

Lawo-Sukam, A. (2001). (A)cercamiento al concepto de la negritud en la literatura afrocolombiana. Cincinnati Romance Review, (30), 39-52.

Mina Aragón, W. (2006). Manuel Zapata Olivella: pensador humanista. Bogotá; Selbstverl.

Nouhaud, D. (2005). La ruta de Chimá al monte Kenia. Palimsestos, (5), 148-166.

Quintero, C. (1998). Filosofía antropológica y cultural en el pensamiento de Manuel Zapata Olivella. Quito: Abya-Yala-Casa de la Cultura de Curumaní Cesar.

Todorov, T. (2010). La conquista de América: el problema del otro. México: Siglo XXI. 
Valdelamar Sarabia, L. (2009). La cuestión del mestizaje y la categoría epistémicoexistencial del Muntú en La rebelión de los genes y Changó el gran putas de Manuel Zapata Olivella. Cuadernos de Literatura del Caribe e Hispanoamérica, 207-217.

Vasconcelos, J. (1999). La raza cósmica. Heredia: Centro de Estudios GeneralesUniversidad Nacional.

Walsh, C. (2009). Interculturalidad, estado, sociedad: Luchas (de)coloniales de nuestra época. Quito: Universidad Andina Simón Bolívar-Abya-Yala.

Zapata Olivella, M. (1974). El hombre colombiano. Bogotá: Canal Ramírez-Antares.

Zapata Olivella, M. (1997). La rebelión de los genes: el mestizaje americano en la sociedad futura. Bogotá: Altamir.

Zapata Olivella, M. (1999). Las claves mágicas de América. Bogotá: Plaza y Janés.

Zapata Olivella, M. (2002). El árbol brujo de la libertad. África en Colombia. Orígenestransculturación-presencia. Ensayo histórico-mítico. Buenaventura: Universidad del Pacífico. 